logos_i_ethos_2013_2_(35), s. 7-25

Marek Sołtysiak

\title{
Istnienie dzieła sztuki \\ a jego tożsamość hermeneutyczna według Hansa-Georga Gadamera
}

Rozważania dotyczące istoty dzieła sztuki odgrywają doniosłą rolę w hermeneutyce filozoficznej Hansa-Georga Gadamera. W trakcie przygotowania do druku książki zatytułowanej Lesebuch (1997), która jest wyborem jego najważniejszych artykułów, zwrócił uwagę Jeanowi Grondinowi, żeby umieścił w niej również prace poświęcone poezji. „Pragnął w ten sposób pokazać, że sztuka - a nie, jak w Wahrheit und Methode, pytanie epistemologiczne

Marek Soltysiak - kapłan, doktor filozofii, adiunkt Katedry Filozofii Poznania Wydziału Filozoficznego Uniwersytetu Papieskiego Jana Pawła II w Krakowie. Zajmuje się filozofią poznania i antropologią filozoficzną. Zainteresowania naukowe: filozofia niemiecka XX wieku (w szczególności: M. Heidegger i H. G. Gadamer) oraz myśl filozoficzna R. Descartesa. o nauki humanistyczne - stanowiła punkt wyjścia jego hermeneutyki. Od tego zbyt jednostronnego punktu wyjścia nauk humanistycznych zdystansował się w 1985 roku"1. Zainteresowania Gadamera związane ze sztuką koncentrują się nie na estetyce, lecz na ontologii dzieła sztuki. W wywiadzie z Grondinem stwierdza, że cała jego filozofia wypływa z refleksji nad sztuką, a nie z estetyki². Estetykę krytykuje za odmówienie sztuce roszczeń do prawdy i rozumienie dzieła sztuki jedynie jako czegoś subiektywnego. Według niego dzieło sztuki ujęte od strony jego istnienia przekazuje prawdę, która wykracza poza jej zawężony przekaz w naukach przyrodniczych ${ }^{3}$.

J. Grondin, Hans-Georg Gadamer. Biografia, tłum. J. Wilk, Wrocław 2007, s. 310.

H. G. Gadamer, Gadamer - Lesebuch, red. J. Grondin, Tübingen 1997, s. 283.

Por. M. Sołtysiak, Między relatywizmem a absolutyzmem. Hermeneutyczna koncepcja prawdy Hansa-Georga Gadamera, [w:] Kondycja człowieka współczesnego, red. C. Piecuch, Kraków 2006, s. 101-113. 
W związku ze sposobem istnienia dzieła sztuki powstaje problem dotyczący sposobu zachowania przez nie tożsamości. Szczególnie dotyczy on dzieł scenicznych. Na przykład inscenizacje dramatu Szekspira Hamlet różnią się między sobą w zależności od tego, kto je reżyserował, gdzie, komu i kiedy zostały wystawione. Czy zatem dzieło sztuki nie rozpada się na różne interpretacje, niezależne od siebie? Gadamer, nawiązując do rozumienia dzieła sztuki w pierwszej połowie XX wieku, pisze, że „eksperyment przekroczył wszelkie granice. Oczekiwanie przez widza obrazowości zostaje umęczone do granic wytrzymałości. Stoimy u kresu długiego wyzwania, które poprzez kubistyczne rozbicie formy, poprzez ekspresjonistyczne zniekształcenie form, poprzez surrealistyczną zagadkowość, przez rosnące pustoszenie obrazu aż po bezprzedmiotowość doprowadziło ostatecznie do śmiałego zwątpienia w obraz i do zwątpienia w sztukę. [...] Artysta pragnie prowokować, irytować i wielu chce swe dzieła rozumieć tylko jako rodzaj propozycji, która zaprasza innych do własnej twórczości i aktywności"4. Samo dzieło sztuki nie stanowi żadnej sensowej całości. Dany nam jest tylko chaotyczny strumień jednorazowych i ulotnych przeżyć, który nie ma żadnej logiki, i nie umożliwia dotarcia do jakiejkolwiek prawdy ${ }^{5}$.

Gadamer przeciwstawia się takiemu rozumieniu dzieła sztuki. Według niego, pomimo różnych prezentacji, każde dzieło sztuki zachowuje swą tożsamość. Głównym celem niniejszego artykułu jest przedstawienie poglądów Gadamera dotyczących tożsamości dzieła sztuki. Rozpoczniemy od rekonstrukcji jego poglądów dotyczących istnienia dzieła sztuki i jego roszczenia do prawdy. A następnie ukażemy jego autonomię i związaną z nią tożsamość hermeneutyczną.

H. G. Gadamer, Dziedzictwo Europy, tłum. A. Przyłębski, Warszawa 1992, s. 48.

F. Chmielowski, Sztuka, sens, hermeneutyka. Filozofia sztuki H. G. Gadamera, Kraków 1993, s. 136: „Współcześni twórcy daleko odeszli od pryncypialnych zasad sztuki awangardowej, która dystansowała się od tradycji; w swoich dziełach nawiązują do dzieł minionych epok lub je cytują albo trawestują, uznając, że ze świadomości ludzkiej nie sposób wymazać śladów przeszłości, nie ma też potrzeby ich usuwania, raczej należy je wykorzystać w procesie tworzenia nowych dzieł". Także i w ich przypadku wciąż aktualne pozostaje pytanie o tożsamość dzieła sztuki. 


\section{Dzieło sztuki jako utrwalona prawda o rzeczywistości}

Gadamer ujmuje byt z perspektywy gry i dochodzi do wniosku, że istotą bytu jest jego autoprezentacja. Źródła takiego rozumienia bytu odnalazł w greckiej metafizyce piękna ${ }^{6}$. Gadamerowskie określenie istoty bytu jako autoprezentacji wykracza poza jej Arystotelowskie określenie jako substancji. Według Stagiryty byt realny jest tym, co w swoim istnieniu i właściwościach jest niezależne od poznającego podmiotu. Natomiast Gadamerowskie określenie istoty bytu jako autoprezentacji nie pozwala na oddzielenie bytu od jego prezentacji, czyli bytu od poznania. Prezentowanie jest prezentowaniem się czegoś, jak również jest prezentowaniem się komuś. Gadamer, określając istotę bytu jako autoprezentację, przeciwstawia się także postmodernistycznemu ujęciu istoty przedmiotu jako pustej formy, która jest wypełniana każdorazowo przez wielość zmiennych przeżyć poznającego podmiotu. W związku $\mathrm{z}$ rozumieniem istoty bytu jako autoprezentacji powstaje pytanie o to, czym jest rzeczywistość tego, co się prezentuje.

Według Gadamera „«Rzeczywistość» mieści się zawsze wewnątrz przyszłościowego horyzontu pożądanych i budzących lęk, w każdym razie jeszcze nierozstrzygniętych możliwości"7. Z różnych przyczyn nie wszystkie możliwości, które człowiek dostrzega w rzeczywistości, mogą być zrealizowane, ponadto realizacja jednych możliwości wyklucza zaistnienie innych. Ten nadmiar możliwości związanych z rzeczywistością, która się człowiekowi prezentuje, powoduje, że sama prawda o niej pozostaje często ukryta. Człowiek, w zetknięciu z przyrodą, doświadcza pewnej nadwyżki sensu w postaci gry jej możliwości (energeia), która przesłania mu to, czym jest ona w swojej prawdzie. Gadamer dostrzega w ujawnieniu prawdy swoiste pole działania dla artysty. Jego zadanie polega na dostrzeżeniu tych możliwości i przemienieniu ich w dzieło sztuki, czyli w wytwór (ergon).

6 Por. H. G. Gadamer, Prawda i metoda. Zarys hermeneutyki filozoficznej, tłum. B. Baran, Warszawa 2004, s. 648-649.

Tamże, s. 172. 
Pojęcie przemiany winno zatem charakteryzować samodzielny i wyższy sposób istnienia tego, co nazwaliśmy wytworem. Na tej podstawie określa się tak zwaną rzeczywistość jako to, co nieprzemienione, a sztukę jako podniesienie tej rzeczywistości do jej prawdy 8 .

Świat prezentuje człowiekowi podczas gry swoje możliwości. Ta prezentacja nie jest czymś wtórnym wobec „rzeczywistego świata” lub jego podobizną, lecz „[...] jest samym tym światem we wzmożonej prawdzie jego bytu”. Artysta „użycza trwania” ${ }^{10}$ temu, co jest grą możliwości. Poprzez przemianę energeia (możliwości) w ergon (w wytwór) ukazuje on w pełnym świetle to, co się zwykle skrywa i wymyka rozumieniu. Tym czymś, czemu on „użycza trwania”, jest istota bytu, która tak a nie inaczej jemu się prezentuje.

Gadamer, utrzymując, że artysta w dziele sztuki utrwala prawdę o rzeczywistości, nawiązuje do starożytnej teorii mimesis - naśladownictwa. „Pojęcie naśladownictwa może jednak opisać grę sztuki tylko wtedy, gdy będziemy uwzględniać sens poznawczy, tkwiący w naśladownictwie. To, co zaprezentowane, istnieje - taka jest pierwotna relacja mimetyczna. Naśladujący pozwala zaistnieć temu, co sam zna, i w sposób, w jaki to zna" ${ }^{11}$. Biorąc pod uwagę relację mimetyczną pomiędzy artystą a tym, co mu się prezentuje, należy zapytać o jego swobodę twórczą. Artysta tworzy zawsze w określonej tradycji, choćby nie był tego świadom ${ }^{12}$. Jego twórczość jest prezentacją pewnej wspólnej prawdy,

8 H. G. Gadamer, Prawda i metoda..., dz. cyt., s. 173.

9 Tamże, s. 203.

10 Por. H. G. Gadamer, Aktualność piękna, tłum. S. Morawski, Warszawa 1993, s. 62-63. Według Gadamera „użyczenie trwania” wyróżnia grę człowieka, a zwłaszcza grę artystyczną, od wszelkich form gier w przyrodzie.

11 Tenże, Prawda i metoda..., dz. cyt., s. 173. Naśladownictwo, jako rozpoznanie istoty, obowiązuje dopóki, dopóty „[...] poznanie prawdy jest poznaniem istoty” (tamże, s. 176). Pojęcie mimesis utraciło to znaczenie dla nominalizmu nowożytnej nauki i jego pojęcia rzeczywistości; w filozofii Kanta straciło ono na znaczeniu w wyniku subiektywnego zwrotu estetyki.

12 Por. M. Sołtysiak, Rozumienie i tradycja w hermeneutyce Hansa-Georga Gadamera, Kraków 2004, s. 151-180. 
która obowiązuje także i jego ${ }^{13}$. Dlatego można powiedzieć, że z jednej strony jest on swobodny w doborze form wyrazu, za pomocą których chce wyrazić wspólną prawdę o rzeczywistości, a z drugiej strony znajduje się w tradycji, której podlega i w ramach której tworzy. Dobiera on zatem takie środki wyrazu, które są zgodne z modą obowiązującą w danej tradycji, a które najlepiej zaprezentują jego dzieło widzom. Nawet wtedy, gdy swoim dziełem chce tylko zaszokować opinię publiczną, środki wyrazu, których używa, są związane ze specyficzną wrażliwością społeczeństwa, w którym żyje. „[...] nie są - one - tylko wtórnymi ilustracjami, lecz temu, co prezentują, pozwalają dopiero być w pełni tym, czym to coś jest"14.

\section{Rozpoznanie prawdy}

Warunkiem koniecznym wyrażenia przez artystę prawdy o rzeczywistości w dziele sztuki jest jej rozpoznanie. „W rozpoznaniu coś nam znanego wyłania się niczym oświetlone z wszelkiej przypadkowości i zmiennych okoliczności, które to coś warunkują, i zostaje ujęte w swej istocie. Zostaje poznane jako coś. [...] Coś «znanego» zyskuje swój prawdziwy byt. I pokazuje się jako to, czym jest, dopiero po rozpoznaniu. Jako rozpoznane, jest zatrzymane w swej istocie, uwolnione od przypadkowości swych aspektów"15. Dzięki rozpoznaniu przez artystę istoty jakiegoś aspektu rzeczywistości i utrwaleniu jej w postaci wytworu, w dziele sztuki zawarta zostaje trwała prawda, która jest uniwersalnie ważna.

To, co zostało przez twórcę rozpoznane i utrwalone w postaci wytworu - ergon, dla swego właściwego istnienia domaga się gry, czyli przejścia na powrót z ergon w energeia, ponieważ dzieło sztuki nie może właściwie istnieć „w sobie”, niezależnie od swej autoprezentacji. Oczywiście, możemy powiedzieć, że dramaty Szekspira istnieją w formie wydania książkowego niejako „w sobie”, ale tylko wtedy ich istnienie jest

\footnotetext{
13 Por. H. G. Gadamer, Prawda i metoda..., dz. cyt., s. 198.

14 Tamże, s. 211.

15 Tamże, s. 174-175.
} 
właściwie, kiedy są wystawiane na scenie, czyli gdy dochodzi do ich prezentacji widzowi. Samo wystawienie, a więc prezentacja odniesiona do dzieła sztuki, jest jego właściwym sposobem istnienia, a nie tylko określonym zachowaniem się twórcy lub odbiorcy.

Kiedy dochodzi do wystawienia dramatu na scenie, mamy do czynienia $\mathrm{z}$ podwójną mimesis i ponownym rozpoznaniem. Aktorzy grający na scenie prezentują to, co autor zawarł w swoim dramacie. On sam natomiast, jak było wyżej ukazane, prezentuje to, co rozpoznał w rzeczywistości. W tym przypadku występuje podwójna mimesis - zarówno autor prezentuje, jak i aktorzy prezentują. Gadamer podkreśla, że temu „podwójnemu rozróżnieniu: literatury i jej materiału oraz literatury i wystawienia, odpowiada podwójne nierozróżnienie jako jedność prawdy, którą się poznaje w grze sztuki” ${ }^{\prime 6}$. Zarówno autor, jak i aktorzy przedstawiają prawdę o rzeczywistości. Podczas gry na scenie prezentuje się to, co aktorzy grają. A wtedy nie ma już ani dramaturga, ani aktorów, których znamy z imienia i nazwiska, lecz istnieje tylko owa prezentacja. Aktorzy grają swoje role, ale nie utożsamiają się z postaciami, które przedstawiają. Natomiast widz całkowicie pogrąża się w grze, rozgrywającej się na scenie.

Według Gadamera gra na scenie doznaje totalnego zwrotu: „Widz zajmuje miejsce grającego. To on - a nie grający - jest tym, dla kogo i w kim rozgrywa się gra" ${ }^{17}$. Zadaniem aktorów jest taka prezentacja dramatu widzom, aby to oni rozpoznali zawartą w nim prawdę. Dlatego widzowie, a nie aktorzy, są tymi, którzy rozpoznają prawdę dzieła sztuki, i to w nich dokonuje się swoista przemiana. Dotychczasowy byt, który znali „[...] naraz i jako całość staje się czymś innym”" ${ }^{18}$. To, co teraz rozpoznali, jest prawdą jego istoty. W porównaniu $\mathrm{z}$ nią, wcześniejsza o nim wiedza, którą posiadali, jest niczym. Byt ukazuje nowe istnienie, które jest zaprzeczeniem starego. Przemiana ta nie zachodzi na drodze stopniowych zmian, lecz staje się nagle. Według Gadamera dochodzi

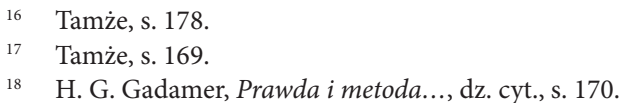


do niej podczas doświadczenia hermeneutycznego. Widz doświadcza $\mathrm{w}$ nim podwójnego rozpoznania. Rozpoznaje on w dziele sztuki nie tylko prawdę o świecie, lecz także o sobie samym. Gadamer pisze w zakończeniu artykułu Estetyka $i$ hermeneutyka: „W dziele sztuki stykamy się z czymś bliskim, a jednocześnie to zetknięcie w zagadkowy sposób wstrząsa nami i burzy zwyczajność. W radosnej i strasznej grozie dzieło sztuki oznajmia: To jesteś ty - ale mówi także: Musisz zmienić swoje ży-

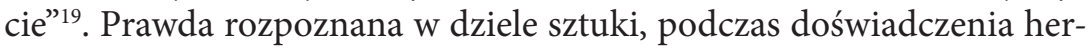
meneutycznego, odnosi się bezpośrednio do życia widza. W jej świetle dotychczasowe jego życie okazuje się życiem nieprawdziwym, w jakiejś ułudzie. Niejako zmusza go do innego widzenia rzeczywistości, która go otacza, i do zmiany własnego życia ${ }^{20}$.

Gadamer uważa, że grającego aktora nie dotyczy przemiana, lecz przebranie $^{21}$. Aktor przebiera się i odgrywa swoje role, zachowując przy tym większy lub mniejszy dystans wobec granej przez siebie postaci. Nie identyfikuje się jednak z nią. Ma tak grać, aby widzowie rozpoznali, dzięki jego grze, prawdę o rzeczywistości i żeby poznana prawda spowodowała w nich przemianę w postrzeganiu świata i samych siebie. W związku z tak ujętą grą aktora w dramacie wydaje się, że Gadamer nie dostrzega jego specyficznej sytuacji, w jakiej się on znajduje. Mianowicie, ażeby aktor mógł prezentować na scenie określoną prawdę o rzeczywistości, wcześniej musiał ją sam rozpoznać w dziele sztuki. Stąd narzuca się wniosek, że rozpoznanie i przemiana wystąpiła najpierw w aktorze, a dopiero później w widzu. W aktorze ta przemiana mogła dokonać się już przy pierwszej lekturze scenariusza dramatu, w którym

19 Tenże, Estetyka i hermeneutyka, tłum. M. Łukasiewicz, [w:] tenże, Rozum, słowo, dzieje. Szkice wybrane, wybrał, opracował i wstępem poprzedził K. Michalski, tłum. M. Łukasiewicz i K. Michalski, Warszawa 1979, s. 127. Gadamer w rozpoznaniu prawdy o sobie samym nawiązuje do pojęcia tragedii Arystotelesa. Por. Arystoteles, Poetyka, [w:] Arystoteles, Dzieła wszystkie, tłum. H. Podbielski, t. 6, Warszawa 2001, s. 563-626.

$20 \quad$ Należy odróżnić prezentację dzieł scenicznych (dramatu czy opery) od niescenicznych (obrazu czy rzeźby). W przypadku tych pierwszych ich prezentacja widzom zapośredniczona jest przez grę aktorów. Jeżeli chodzi o dzieło sztuki niesceniczne, to prezentuje ono widzowi bezpośrednio prawdę o rzeczywistości i o nim samym.

${ }^{21}$ Por. H. G. Gadamer, Prawda i metoda..., dz. cyt., s. 171. 
ma on zagrać. Grając na scenie, przedstawia on widzom prawdę, którą już wcześniej sam rozpoznał. Dopiero biorąc pod uwagę powyższe dopowiedzenie, można zgodzić się z twierdzeniem Gadamera, że przemiana nie dotyczy aktora grającego na scenie, lecz widza.

\section{Autonomia dzieła sztuki}

Dzieło sztuki, kiedy jest wytworem (ergon), domaga się dla swego właściwego zaistnienia swoistej gry (energeia), w której bierze udział zarówno aktor, jak i widz. Ten, kto podejmie wezwanie do gry płynące z dzieła sztuki, ma takie samo prawo do jego interpretacji, jak jego twórca. Dlatego artysta, który stworzył dzieło sztuki, nie ma pierwszeństwa w jego autointerpretacji przed jego odbiorcami.

Jednakże autonomia dzieła sztuki pojawia się o wiele wcześniej niż podczas ponownej jego interpretacji. Uzyskuje ono wolność od planów twórcy w końcowym etapie swego powstawania. Gadamer zwraca uwagę na „skok” występujący pomiędzy tym, co artysta zaplanował i zamierzał osiągnąć, a rezultatem, którym jest zaistniałe dzieło sztuki jako wytwór. Pisze on w Aktualności piękna, że:

„Wytwór” nie jest przed wszystkim czymś, o czym można sądzić, że zostało zrobione w sposób zamierzony (co wciąż jeszcze zwykło się łączyć z pojęciem dzieła). Kto stworzył dzieło sztuki, stoi w istocie przed dziełem swoich rąk nie inaczej niż każdy inny. Między planowaniem i wykonaniem, z jednej strony, a udanym rezultatem $z$ drugiej, mamy do czynienia ze skokiem. I oto dzieło „jest”, a zarazem jest „tu oto” raz na zawsze; znajdzie je każdy, ktokolwiek wyjdzie mu naprzeciw, każdy też może wejrzeć w jego „jakość”. Ten skok wyróżnia dzieło sztuki, czyni je jedynym i niezastąpionym. Jest tym, co Walter Benjamin nazywał aurą dzieła sztuki i co znamy wszyscy, choćby w oburzeniu na to, co zwiemy „bluźnierstwem" wobec sztuki. Zniszczenie dzieła sztuki ma dla nas wciąż jeszcze coś z bluźnierstwa religijnego ${ }^{22}$.

22 Tenże, Aktualność piękna..., dz. cyt., s. 44-45. 
Zaistnienie dzieła sztuki odróżnia się od istnienia rzeczy, którymi człowiek się otacza i których używa w swoim codziennym życiu. Człowiek wytwarza przede wszystkim rozmaite użyteczne sprzęty. Są one dla niego wyrobami, środkami i narzędziami, przydatnymi w codziennym życiu i w pracy. Produkuje się je zwykle seryjnie. Są naprawiane, gdy się zepsują. Udoskonala się ich funkcjonowanie i zastępuje innymi egzemplarzami, bardziej wydajnymi. Ludzie nie interesują się zbytnio losem tych starych, często zużytych narzędzi, a jeśli już, to jako eksponatami w muzeach techniki. Dzieło sztuki, w przeciwieństwie do narzędzi, jest jedyne i niepowtarzalne, i jako takie jest niezastąpione. Tym odróżnia się od innych osiągnięć ludzkości w dziedzinie techniki i rzemiosła, że oznacza pewien przyrost bytu ${ }^{23}$.

Istnienie dzieła sztuki jest autonomiczne wobec swego pierwowzoru, tzn. wobec rzeczywistości i jej możliwości, które były powodem jego powstania. Z powodu wystąpienia „skoku” w jego zaistnieniu, nie jest ono także lustrzanym odbiciem tej rzeczywistości. W niektórych przypadkach, po zaistnieniu wytworu (dzieła sztuki), pomiędzy nim a jego pierwowzorem zachodzi relacja zwrotna. Dla Gadamera wymownym przykładem, egzemplifikującym tę relację jest portret prezentujący władcę. Artysta w portrecie uchwycił określone możliwości dostrzeżone w pierwowzorze, tzn. w portretowanym władcy. Te możliwości, utrwalone w namalowanym portrecie, są rozpoznaną prawdą o nim. Ponieważ portret reprezentuje władcę, dlatego oczekuje się od niego, że jego zachowanie będzie zgodne $z$ ową rozpoznaną prawdą.

Nie tylko portret, lecz każda prezentacja dzieła sztuki jest pewnym procesem bytowym, która ukazuje znaczenie tego, co jest prezentowane. Według Gadamera „przez prezentację to coś doznaje niejako przyrostu bytu. Własna treść obrazu jest określona ontologicznie jako emanacja pierwowzoru. Do istoty emanacji należy, że coś emanowanego stanowi pewien nadmiar. Tego, z czego to coś wypływa, nie ubywa przez to. Rozwinięcie tej idei przez filozofię neoplatońską, która w ten sposób rozsadza granice greckiej ontologii substancji, uzasadnia 
pozytywną rangę bytową obrazu. Jeśli bowiem pierwotnego Jednego nie ubywa przez wypływ wielości z niego, to oznacza to przecież, że przybywa bytu"24.

Można powiedzieć, że dlatego „przybywa bytu”, ponieważ podczas prezentacji (energeia) niektóre możliwości bytu zostały rozpoznane i utrwalone (ergon). Dzieło sztuki, które jest ich utrwaleniem, ukazuje rozpoznaną prawdę o rzeczywistości. Ta rozpoznana prawda o rzeczywistości niejako rozbija dotychczasową wiedzę twórcy o niej. Omawiany powyżej „skok”, związany z zaistnieniem dzieła sztuki, wykracza poza wyobrażenie twórcy, jakie on posiadał o rzeczywistości. Artysta ma do czynienia, z jednej strony, z pewnym pierwowzorem, a z drugiej strony $-\mathrm{z}$ jego utrwaleniem $\mathrm{w}$ postaci dzieła sztuki, które jest autonomiczne wobec niego. Dlatego „z perspektywy poznania prawdy, byt przedstawienia jest czymś więcej niż bytem prezentowanego materiału. Achilles Homera [jest] czymś więcej niż jego pierwowzór"25. Dzięki rozpoznaniu nie tylko coś zaistniało, ale zaistniało bardziej właściwie, ponieważ została rozpoznana jego istota. Rozpoznanie nie jest powtórzeniem czegoś, co jest już znane, lecz jest ukazaniem jego prawdy, która następnie została utrwalona w postaci dzieła sztuki.

Autonomia dzieła sztuki, tak ujęta przez Gadamera, wykracza poza, a nawet unieważnia sławną wypowiedź Schleiermachera, że „mamy pisarza rozumieć lepiej, niż on sam siebie rozumiał”. To „lepsze rozumienie", cechujące interpretatora, dotyczy autora tekstu, a nie samego dzieła sztuki. Biorąc pod uwagę Gadamerowskie wystąpienie „skoku” w ukończonym dziele sztuki, należy stwierdzić, że własne rozumienie autora dzieła sztuki nie jest tym samym, co zrozumienie samego dzieła sztuki, które on stworzył. W związku z tym pytanie, co autor miał na myśli, tworząc dzieło sztuki, może jest i ciekawe, ale nie dotyczy samego dzieła sztuki. Również kongenialność interpretatora nie wystarczy, aby zrozumieć dzieło, które stworzył genialny twórca. Dzieło sztuki w trakcie powstawania zyskało niezależność od swego twórcy.

24 H. G. Gadamer, Prawda i metoda..., dz. cyt., s. 207-208.

25 Tamże, s. 175. 


\section{Tożsamość hermeneutyczna dzieła sztuki}

Odmiany inscenizacji i realizacji dzieła sztuki są zależne zarówno od grających, jak i od samego dzieła sztuki. Jeżeli idzie o wpływ grających na prezentację dzieła sztuki, to jest ona związana z ich subiektywnymi przeżyciami i poglądami, które dotyczą ich interpretacji i związanej z nią gry. W ich poczynaniach nie ma jednak dowolności. Granicą interpretacji jest samo dzieło sztuki i jego możliwości bytowe. Dzieło sztuki, dzięki istniejącej w nim wielości aspektów, pozwala się tak a nie inaczej interpretować podczas gry. Sama gra musi stanowić sensowną całość, aby dzieło sztuki osiągnęło swój właściwy byt ${ }^{26}$.

Dzieło sztuki dla swego właściwego zaistnienia domaga się gry - energeia, która przemienia się w ergon - wytwór. Osiąga ono pełnię swego bytu podczas każdorazowej aktualnej prezentacji. Jak to się jednak dzieje, że dzieło sztuki, pomimo twórczych przekształceń podczas prezentacji przez kolejne pokolenia twórców, zachowuje swoją tożsamość?

Dzieło sztuki, jako gra, do swego właściwego zaistnienia potrzebuje tego, komu się zaprezentuje. Ale tylko ten podejmie jego grę, kto dostrzeże, że ma mu ono coś ważnego do powiedzenia. Chcąc mówić o tożsamości dzieła sztuki, należy wziąć pod uwagę to zapytywanie płynące z dzieła sztuki oraz domaganie się przez nie właściwej odpowiedzi. Dlatego Gadamer, zamiast o tożsamości dzieła sztuki jako czegoś stałego i niezmiennego (do czego można się odwoływać), mówi o tożsamości hermeneutycznej. Zgodnie z nią, dzieło sztuki chce być zrozumiane przez tego, kto chce słuchać jego mowy. Wychodzi „[...] od «dzieła» wyzwanie, które czeka na to, by mu ktoś sprostał. Domaga się odpowiedzi, udzielić jej zaś może tylko ten, kto to wyzwanie przyjął. Ta odpowiedź musi więc być jego własną odpowiedzią, której sam czynnie udziela. Gra wymaga współgrającego" 27 .

Biorąc pod uwagę analizy Gadamera dotyczące tożsamości hermeneutycznej dzieła sztuki, można wskazać jej trzy podstawowe cechy. Po

\footnotetext{
26 Por. H. G. Gadamer, Prawda i metoda..., dz. cyt., s. 179.

27 Tenże, Aktualność piękna..., dz. cyt., s. 34.
} 
pierwsze: każdorazowa prezentacja dzieła sztuki jest powtórzeniem tego samego; po drugie: podczas kolejnych prezentacji dzieła sztuki występuje ciągłe odwoływanie się do tradycji jego wystawienia; i po trzecie: w dziele sztuki są zawsze jakoś obecne okoliczności związane z jego powstaniem.

Ad 1. Podstawową cechą tożsamości hermeneutycznej dzieła sztuki jest powtórzenie tego samego podczas kolejnych jego prezentacji. Gadamer, aby wyjaśnić, na czym polega powtórzenie tego samego, występujące w prezentacji dzieła sztuki, odwołuje się do doświadczenia święta ${ }^{28}$. Święto jest obchodzone cyklicznie co roku. Kolejne jego obchody nie są czymś innym od ostatnich, ale także nie są ich przypomnieniem ani powtórzeniem $^{29}$. Święto, które jest obchodzone, jest równie pierwotne jak samo wydarzenie, które jest powodem tego świętowania. Albowiem świętowanie polega na uobecnieniu tu i teraz tego, co jest świętowane. Chociaż samo obchodzenie święta zmieniało się w różnych okresach historycznych, ponieważ za każdym razem było z nim równoczesne coś innego, to mimo to jest ono zawsze tym samym świętem. W jego obchodzeniu relacje historyczne są drugorzędne. Byt święta polega wyłącznie na stawaniu się i powracaniu tego samego wydarzenia. Jest ono obchodzone, ponieważ istnieje, natomiast ludzie w nim uczestniczą. „Uczestnictwo oznacza udział. Ktoś, kto w czymś uczestniczył, wie w pełni, jak naprawdę było. Dopiero w pochodnym sensie uczestnictwo oznacza też sposób subiektywnego zachowania, "zaangażowania w coś»" ${ }^{30}$. Święto jest równoczesne z wydarzeniem, które jest obchodzone. Podczas jego obchodów zostaje pokonany dystans czasowy pomiędzy przeszłością a teraźniejszością. Kto na przykład uczestniczy w święcie religijnym, ten ma udział w samym procesie zbawczym, którego to święto dotyczy ${ }^{31}$.

Pomiędzy obchodzeniem święta a prezentacją dzieła sztuki Gadamer dostrzega podobieństwo. Byt dzieła sztuki polega na

\footnotetext{
28 Por. tamże, s. 56.

29 Por. H. G. Gadamer, Prawda i metoda..., dz. cyt., s. 138.

30 Tamże, s. 186-187.

31 Por. tamże, s. 191.
} 
prezentowaniu się odbiorcy. Czyli dla swego właściwego zaistnienia domaga się jego udziału w swej grze. Pomimo różnych prezentacji i związanych z nimi wypaczeń ze strony współgrających (reżyserów, artystów i odbiorców), ciągle pozostaje ono sobą. Zachowuje tożsamość hermeneutyczną, ponieważ jego prezentacja „[...] ma w nieusuwalny sposób charakter powtórzenia tego samego. Powtórzenie nie oznacza tu jednak, że coś jest we właściwym sensie powtarzane, tj. sprowadzane do czegoś pierwotnego. Raczej każde powtórzenie jest równie pierwotne jak samo dzieło" 32 . Czym jest „to samo", powtarzane każdorazowo podczas prezentacji? Jak to już wielokrotnie powtarzaliśmy, dzieło sztuki osiąga swój właściwy byt podczas gry. Tym natomiast, co się wówczas prezentuje, jest prawda o świecie, którą każdorazowo widz uczestniczący w przedstawieniu powinien rozpoznać. Przez jej rozpoznanie poznaje on również swoje zbłądzenie. Można zatem powiedzieć, że powtórzenie tego samego w dziele sztuki jest ukazaniem prawdy o świecie podczas jego prezentacji. A ponieważ widz rozpoznaje tę prawdę z własnej sytuacji hermeneutycznej, w której się znajduje, dlatego ta prawda, zastosowana do jego życia, ukazuje mu jego własne zbłądzenie, $\mathrm{z}$ którego teraz może się wyzwolić. Każdy, komu dzieło sztuki się prezentuje, poznaje prawdę własnego religijnego i moralnego świata, w którym żyje ${ }^{33}$.

Byt dzieła sztuki ma pierwszeństwo przed swym twórcą, przed aktorami i reżyserem, jak również przed widzem, który je ogląda. Dla tego, kto doświadcza mowy dzieła sztuki, tracą swe znaczenie wszelkie odległości czasowo-przestrzenne, w których ono powstało, ponieważ on sam uczestniczy w procesie jego prezentacji. Dzieło sztuki, które mu się prezentuje, jest dla niego czymś równoczesnym. „«Równoczesność» natomiast oznacza tu, że coś jedynego, co się nam prezentuje, niezależnie od tego, jak odległe byłoby tego czegoś źródło, w swej prezentacji osiąga pełną obecność" ${ }^{34}$. Mamy równoczesny dostęp do wszystkich dzieł z różnych epok i stylów. Gadamer pisze, że „myśliciel i poeta

\footnotetext{
32 Tamże, s. 184-185.

Por. tamże, s. 192.

Tamże, s. 190.
} 
przemawia do nas tak bezpośrednio, jak potrafią to czynić wielkie arcydzieła wszystkich czasów"35.

Można powiedzieć, że dzieło sztuki, zgodnie ze swoją istotą, mówi zawsze to samo, ale nie tak samo. Przekazuje tę samą prawdę o rzeczywistości, ale nie tak samo, ponieważ mówi do konkretnego odbiorcy, któremu przez to ukazuje prawdę o nim samym. Dlatego „idea jedynego właściwego przedstawienia wydaje się w ogóle czymś sprzecznym ze skończonością naszego dziejowego jestestwa. [...] Tutaj oczywisty fakt, że każde przedstawienie chce być właściwe, potwierdza tylko, że nieodróżnianie pośrednictwa od samego dzieła jest właściwym doświadczeniem dzieła" ${ }^{36}$. Wtedy mamy do czynienia $\mathrm{z}$ właściwą prezentacją dzieła sztuki, kiedy nie możemy odróżnić jego prezentacji (wytworu) od niego samego (od samego dzieła sztuki).

Należy zaznaczyć, że czymś innym, niż wyżej opisane nieodróżnianie pośrednictwa od samego dzieła sztuki, jest porównywanie odmian jego inscenizacji przez różnych reżyserów. Związane jest ono z prezentacją jego wielorakich aspektów, które odpowiadają na aktualną sytuację hermeneutyczną: zarówno reżyserów, jak i aktorów biorących udział w przedstawieniach. Innym przykładem odróżnienia dzieła od jego prezentacji, który podaje Gadamer, jest konserwacja obrazu z minionych wieków, dokonywana przez konserwatora sztuki ${ }^{37}$. W tym przypadku konserwator bierze pod uwagę różne możliwe odmiany prezentacji samego dzieła sztuki. W każdym z tych dwóch przypadków możemy jednak mówić o powtórzeniu tego samego, które odnosi się do właściwej prezentacji samego dzieła sztuki.

Gadamer wskazuje też na taką prezentację dzieła sztuki, w której nie jest ona powtórzeniem tego samego. Ma to miejsce w przypadku całkowicie zniekształconej prezentacji. Polega ona na tym, że prezentację rozumie się i ocenia jako prezentację samego wytworu, a nie dzieła sztuki ${ }^{38}$.

\footnotetext{
35 H. G. Gadamer, Dziedzictwo Europy, tłum. A. Przyłębski, Warszawa 1992, s. 102.

36 Tenże, Prawda i metoda..., dz. cyt., s. 181.

37 Por. tamże, s. 179.

38 Por. tamże s. 184
} 
Ad 2. Drugim wyznacznikiem tożsamości hermeneutycznej dzieła sztuki jest potrzeba, podczas kolejnych jego prezentacji, ciągłego odwoływania się do tradycji jego wystawiania. Prezentacje dzieła sztuki nie są ani nieograniczone, ani dowolne. Muszą brać pod uwagę przede wszystkim samo dzieło sztuki i jego „zasady gry”, jak również całą tradycję, związaną z jego poprzednimi prezentacjami. „Znamy to ze współczesnego teatru jako tradycja wychodząca od inscenizacji, charakteru ról lub praktyki wystawienia dzieła muzycznego. Nie mamy tu przypadkowego następstwa różnych odmian ujęć: raczej ze stałego odwoływania się do wzorca i twórczych jego przekształceń tworzy się tradycja, do której każda nowa próba musi się odwołać" 39 .

Aby jednak sprostać mowie dzieła sztuki i jego wyzwaniu, tzn. w jego twórczym odniesieniu do swej własnej sytuacji, należy nauczyć się jego gry. Szczególnie wyraźnie to widać podczas spotkania widza z dziełami sztuki współczesnej. Rewolucja, która nastąpiła w sztuce w XX i XXI wieku, zagraża zachowaniu tożsamości przez dzieło sztuki. Twórca oczekuje od odbiorcy tak dużej aktywności przy jego odczytywaniu, że dzieło zaczyna tracić swoją tożsamość. „Artysta pragnie prowokować, irytować i wielu chce swe dzieło rozumieć tylko jako rodzaj propozycji, która zaprasza innych do własnej twórczości i aktywności” ${ }^{40}$. Odbiorca ma nie tylko rozumieć dzieło sztuki (ars interpretandi), lecz ma je przede wszystkim współtworzyć.

Z drugiej strony, jak podkreślał Heidegger, współczesna sztuka jest odzwierciedleniem marnego czasu, w którym przyszło nam żyć. Gadamer, niejako parafrazując jego myśl, mimo swej krytycznej oceny sztuki współczesnej, dostrzega jednak w niej także pozytywne cechy. „Kto sądzi, że nowoczesna sztuka jest zwyrodniała - pisze w Aktualności pięk$n a-$ nie pojmuje rzeczywiście wielkiej sztuki poprzednich epok. Należy się przekonać, że najpierw się trzeba nauczyć każde dzieło sylabizować, a potem czytać, i dopiero wtedy zaczyna ono mówić. Sztuka nowoczesna jest dobrym ostrzeżeniem przed wiarą, że nie sylabizując, nie

39 Tamże, s. 180.

40 H. G. Gadamer, Dziedzictwo Europy..., dz. cyt., s. 48. 
nauczywszy się czytać, można usłyszeć mowę dawnej sztuki”41. W powyższej wypowiedzi Gadamer nawiązuje do oświeceniowej idei kształcenia. Aby zrozumieć dzieła sztuki z każdej epoki, a nie tylko sztuki nowoczesnej, najpierw musimy poznać ich „alfabet i język”, którymi one do nas mówią.

Ad 3. Trzecią cechą tożsamości hermeneutycznej dzieła sztuki jest jego okazjonalność. Dzieło sztuki powstało z racji jakiejś okazji, aby spełnić określoną funkcję, do której zostało przeznaczone przez swego twórcę. Przyczyna jego powstania, którą Gadamer nazywa okazjonalnością, jest w nim ciągle obecna. Nawet wtedy tkwi w nim i dookreśla je, gdy nie jest jeszcze do końca odkryta. Jej obecność w dziele sztuki nie jest zależna od kaprysu badacza i jego interpretacji. Dzieło sztuki, ze względu na swoją pierwotną okazjonalność, ciągle domaga się dla siebie odpowiedniego sposobu prezentacji, aby mogło spełnić zadanie, do którego zostało powołane od chwili swego zaistnienia.

Tym, co ono prezentuje, jest prawda religijna, moralna bądź też społeczna. Każda z tych prawd domaga się swego zaistnienia podczas kolejnej prezentacji dzieła sztuki. Tylko ten podejmuje owe wezwania, kto je dostrzega i pozwala im się zaprezentować. W tym sensie dzieło sztuki jest współczesne w każdej epoce dla tego, kto odpowiada na jego grę. Czyli, inaczej mówiąc, kto stworzy odpowiednie okoliczności do jego prezentacji.

Dzieła sztuki niejako dookreślają się od okazjonalności do następnej okazjonalności i przez to są współczesne dla każdego człowieka.

Dopóki pełnią [one - przyp. aut.] swe funkcje, są współczesne każdej epoce. Nawet zajmując już tylko miejsce w muzeach jako dzieła sztuki, nie ulegają całkowitemu wyobcowaniu. Chodzi nie tylko o to, że dzieło sztuki nigdy nie traci śladów swej pierwotnej funkcji i umożliwia fachowcowi poznanie jej i odtworzenie dzieła, któremu przydzielono miejsce w galerii pośród innych dzieł, ciągle jeszcze pozostaje własnym światłem. Eksponuje ono siebie, a sposób, w jaki to czyni - „unicestwiając” inne dzieło lub dobrze się z nim uzupełniając - jest sprawą jego natury. Pytamy o tożsamość

${ }^{41}$ Tenże, Aktualność piękna..., dz. cyt., s. 65. 
tej natury, w trakcie zmian epok i warunków tak rozmaicie się prezentującej. Nie rozpada się ona na zmienne aspekty, tracąc tożsamość, lecz jest w nich wszystkich obecna. Wszystkie one jej przysługują. Wszystkie są z nią równoczesne ${ }^{42}$.

Ze względu na swą okazjonalność portret jest portretem nawet wtedy, gdy nie jesteśmy w stanie rozpoznać sportretowanej osoby. Ołtarz pergamoński, chociaż znajduje się w muzeum w Berlinie, nie stracił swojego pierwotnego przeznaczenia, tzn. swego bycia przedmiotem kultu w świątyni.

Okazjonalność zawarta w dziele sztuki umożliwiała i w dalszym ciągu umożliwia dziełu sztuki prezentowanie się ludziom w różnych czasach i w zmiennych warunkach ich życia. W dziele sztuki istnieją tak liczne możliwości, że „siła wypowiedzi samego dzieła” wypełnia każdą przygodność, w której ono się prezentuje. W tej grze nie ma jednak szczeliny, jak chciał to widzieć historyzm, przez którą można by rozpoznać znaczenie dzieła w epoce, w której ono powstało. Dzieło sztuki, będąc grą, zdane jest na prezentację i dlatego oddziałuje ono za każdym razem inaczej, w zależności od tego, komu się prezentuje.

\section{Podsumowanie}

Według Gadamera rzeczywistość jest grą możliwości, ponieważ istotą bytu jest jego autoprezentacja. Zadaniem artysty jest rozpoznanie tych możliwości (energeia), czyli prawdy o rzeczywistości i utrwalenie jej w postaci dzieła sztuki (ergon). Dzieło sztuki istnieje właściwie podczas gry, czyli w trakcie swojej prezentacji widzowi. Jeżeli widz podejmie to wezwanie, płynące z dzieła sztuki, rozpozna prawdę o rzeczywistości i o sobie samym. Poznanie prawdy o sobie samym jest doświadczeniem negatywnym, ponieważ ukazuje widzowi jego życie jako pogrążone w jakiejś ułudzie i burzy mu dotychczasowy obraz świata. Rozpoznana prawda powoduje przemianę w jego życiu.

42 Tenże, Prawda i metoda..., dz. cyt., s. 182. 
Każde dzieło sztuki posiada swoją autonomię. Biorąc pod uwagę na przykład dramat, możemy powiedzieć, że pomiędzy tym, co dramaturg zamierzał napisać, a tym, co powstało, wystąpił swoisty „skok”. Polega on na tym, że końcowy efekt, którym jest gotowy tekst dramatu, wykracza poza planowanie i wyobrażenie, jakie miał o nim jego twórca w trakcie pisania. Ten „skok” występuje w przypadku każdego ukończonego dzieła sztuki. Dzieło sztuki, stanowiąc sensowną całość, wykracza nie tylko poza zamiar swego twórcy, ale także poza to, co istnieje w przyrodzie. Jest czymś jedynym i niepowtarzalnym, i jako takie stanowi przyrost bytu. Ze względu na pojawienie się „skoku” w dziele sztuki, autointerpretacja twórcy jest równorzędna $\mathrm{z}$ interpretacją rozmaitych jego odbiorców.

Autonomia dzieła sztuki jest podstawą jego tożsamości hermeneutycznej. Istotą dzieła sztuki jest jego autoprezentacja. Dzieło sztuki, będąc grą, dla swego właściwego zaistnienia potrzebuje zaprezentowania widzowi, czyli potrzebuje przejścia na powrót z wytworu (ergon) w grę ze swoim odbiorcą (energeia). Pomimo tego, że dzieło sztuki jest prezentacją (grą), zachowuje ono swą tożsamość hermeneutyczną.

Zasadniczą cechą jego tożsamości jest powtórzenie tego samego w każdej prezentacji. Tym, co ono prezentuje w swoich kolejnych inscenizacjach rozmaitym widzom, jest zawarta $\mathrm{w}$ nim, rozpoznana prawda o rzeczywistości. Właściwym sposobem odbioru dzieła sztuki przez widza jest jego włączenie się do gry z nim. Dzięki temu udziałowi w grze widz doświadcza (z perspektywy własnej sytuacji hermeneutycznej) zarówno prawdy o rzeczywistości, jak i własnego bycia w nieprawdzie.

A ponieważ sytuacja hermeneutyczna zarówno kolejnych reżyserów dramatu, jak i widzów zmienia się, dlatego Gadamer zwraca uwagę na konieczność ciągłego odwoływania się do tradycji jego wystawiania. Branie pod uwagę poprzednich prezentacji dzieła sztuki chroni je przed zupełną dowolnością reżysera i pozwala uniknąć nietrafnego rozpoznania prawdy o rzeczywistości w nim zawartej. Występująca w prezentacji dzieła sztuki ciągłość z tradycją inscenizacji stanowi drugi element jego tożsamości hermeneutycznej. 
Natomiast trzecim jej wyznacznikiem jest okazjonalność, czyli przyczyna powstania i przeznaczenia dzieła sztuki, która, pomimo upływu czasu i różnych prezentacji, ciągle jest w nim obecna. Dzięki niej dzieło sztuki nie traci swego pierwotnego przeznaczenia i niejako domaga się dla swojej prezentacji odpowiedniego miejsca i czasu. Biorąc pod uwagę tożsamość hermeneutyczną dzieła sztuki, można powiedzieć, że „dzisiejszy obserwator nie tylko widzi inaczej, lecz widzi co innego" ${ }^{43}$. Dostrzega prawdę świata, w którym żyje i prawdę o swej własnej egzystencji w tymże świecie. 